\title{
Net Increase Rates and Dynamics of Phytoplankton Populations Under Hypereutrophic and Eutrophic Conditions
}

\author{
Yoshio Ogawa
}

\begin{abstract}
The relationships between net increase rates of phytoplankton populations and ambient concentrations of nutrients were investigated in hypereutrophic Himonya Pond and eutrophic Lake Nakanuma, and were expressed by a hyperbolic function for Microcystis aenuginosa, Cyclotella kützingiana and Scenedesmus quadricauda. M. aenuginosa increased faster than the other species in low concentrations of total inorganic nitrogen, whereas C. kützingiana and S. quadricauda increased faster than $M$. aeruginosa in low concentrations of phosphate phosphorus.

Using a mathematical model based on these relationships, the population dynamics of the planktonic algae were analyzed in hypereutrophic conditions and slightly eutrophic conditions. In hypereutrophic conditions, a large amount of phosphate phosphorus caused $M$. aeruginosa to develop into a large population, and then caused the phytoplankton diversity to drop to a low level. On the other hand, in slightly eutrophic conditions, phytoplankton did not develop into large populations, and thus the phytoplankton diversity remained at a high level. This was because low nutrient concentrations limited the population increase of each species. The results of the model analysis coincided with the patterns observed in the field surveys, and showed that the amount of nutrients available for phytoplankton played an important role in the regulation of phytoplankton dynamics.
\end{abstract}

Key Words : population dynamics, diversity, mathematical model, trophic status

\section{Introduction}

Seasonal changes in phytoplankton communities is caused by interspecific competition resulting from differences in responses of individual phytoplankton species to successive environmental changes. In regard to these changes, nutrients are one of the most important factors in determining species composition and dynamics of phytoplankton communities. Therefore, equations have been developed to express species-specific nutrient utilization and its relation to population growth. CAPERON (1967) and Dugdale (1967) showed that rates of nutrient uptake by phytoplankton depend on external nutrient concentrations, and that this relationship was described by the MichaelisMENTEN equation where the essential features were explained by the two parameters, $K_{s}$, the halfsaturation constant and $V_{\mathrm{m}}$, the maximum nutrient uptake rate. Eprley and ThOmas (1967) demonstrated experimentally that the relationship between specific growth rates of phytoplankton and ambient nutrient concentrations are expressed by the Mosor) equation.

By considering the specific characteristics of nutrient uptake and growth responses of phytoplankton, many investigators elucidated the distribution of phytoplankton species. EPPLEY and Thomas (1969) and CARPENTER and GulLlard (1971) showed that phytoplankton species with higher $K_{s}$ values for nitrate uptake predominated in eutrophic waters, whereas phytoplankton species with lower $K_{s}$ values predominated in oligotrophic waters. On the basis of the MONOD equation, TILMAN (1977) explained the horizontal distribution of Asterionella formosa and Cyclotella meneghiniana in the river plume and the offshore region of Lake Michigan. He emphasized that the $K_{s}$ values for limiting nutrients and the ratio between limiting nutrients were the essential factors in explaining the relative abundance of phytoplankton species. These studies clarified phytoplankton distributions in relation to nutrient conditions at a given time. However, during seasonal changes of phytoplank- 
ton communities, the nutrient conditions in waters change because of phytoplankton population growth. The changes in nutrient conditions then control the phytoplankton growth. However, there is less information available about mechanisms which control seasonal changes of phytoplankton communities.

Therefore, this study will explain seasonal changes in phytoplankton communities by analyzing net increase rates in phytoplankton populations with various nutrient concentrations. It will be shown that the amounts of nutrients at the beginning of the growth season are important in controlling seasosal changes of phytoplankton.

\section{Materials and methods}

Field surveys were carried out in hypereutrophic Himonya Pond and eutrophic Lake Nakanuma from 1974 to 1976. Samples from the water column above the thermocline were collected with an integrating sampler. This sampler collects homogeneous phytoplankton samples in a complete column of water down to a desired depth (LiNI) and TALLING, 1957). The collected water was then filtered through glass fiber filters (Whatman GF/ C). Nutrient (phosphate, ammonium, nitrate and nitrite) concentrations in the filtrate samples were measured by the methods described by STRICKLANI) and PARsoNs (1972). The phytoplankton cells in the water samples were preserved in Lugol's solution, and then identified and counted under a microscope. In low density phytoplankton samples, cells were counted after concentrating them 10 times by centrifugation for $15 \mathrm{~min}$ at 3,000 r.p.m.

The population increase of each phytoplankton species was approximated by the logistic equation,

$$
n=\frac{K}{1+k \cdot e^{-m t}}
$$

where $n$ is the cell number at time $t, K$ is the maximum cell number attainable $\left(\right.$ cells $\left.\cdot \mathrm{ml}^{-1}\right), m$ is the intrinsic growth rate $\left(\mathrm{day}^{-1}\right)$ and $k$ is the integration constant. The values of $m$ and $k$ were determined by using the observed $n$ and $K$. The net increase was calculated by the following equation based upon the number of cells estimated from the logistic equation,

$$
r=\frac{\ln n_{2}-\ln n_{1}}{t_{2}-t_{1}}
$$

where $r$ is the net increase rate $\left(\right.$ day $\left.^{-1}\right)$, and $n_{1}$ and $n_{2}$ are the calculated number of cells $\left(\right.$ cells $\left.\cdot \mathrm{ml}^{-1}\right)$ at $t_{1}$ and $t_{2}$, respectively. Phytoplankton diversity was calculated by the SHANN()N-W Walke function (1963)

\section{Results}

\section{3-1. Population increase in natural phyto- plankton communities}

In situ increase in three representative species populations in hypereutrophic Himonya Pond and eutrophic Lake Nakanuma are shown in Figure 1. Microcystis aeruginosa was the most dominant phytoplankton in Himonya Pond during the summer. Cyclotella kützingiana and Scenedesmus quadricauda prevailed in Lake Nakanuma during the summer. The logistic parameters are summarized in Table 1.

The temporal changes in the net increase rate $(r)$ of each population are also shown in Figure 1. The net increase rates were high in the initial stage, and gradually decreased as the season progressed. The lower values occurred during the later growth stage.

3-2. Relationship between net increase rates of phytoplankton populations and nutrient concentrations

The net increase rates of the phytoplankton populations on each sampling day were plotted against the in situ concentrations of total inorganic nitrogen (ammonium + nitrite + nitrate) and phosphate (Fig. 2). The net increase rate increased with increases in nutrient concentrations, although some low net increase rates were found at high nutrient concentrations. These low values might be due to environmental factors other than nutrients. Eliminating these low values, the relationship between the net increase rates of phytoplankton populations and ambient concentrations of nutrients was considered. After the MoN(on) equation, the relationship between the net increase rate and nutrient concentration was expressed by the following hyperbolic equation,

$$
r_{i j}=\alpha_{i j} \frac{\left(s_{j}-s_{i j}^{\prime}\right)}{\beta_{i j}+\left(s_{j}-s_{i j}^{\prime}\right)}
$$

where $r_{i j}$ is the highest net increase rate of the $i$-th species $\left(\right.$ day $\left.^{-1}\right)$ when the ambient concentration of the $j$-th nutrient is $s_{j}\left(\mu \mathrm{g}-\mathrm{at} \cdot \mathrm{l}^{-1}\right), \quad \alpha_{i j}\left(\right.$ day $\left.^{-1}\right)$ and $\beta_{i, j}\left(\mu \mathrm{g}\right.$-at $\left.\cdot 1^{-1}\right)$ are constants of the $i$-th species for the $j$-th nutrient, and $s_{i j}^{\prime}$ is the ambient concentration of the $j$-th nutrient at which no increase in the $i$-th population occurs. $\alpha_{i j}$ and $\beta_{i j}$ were determined by the least square method, and $s_{i, j}^{\prime}$ was adjusted to the value at which $r_{i j}$ became -0.01 


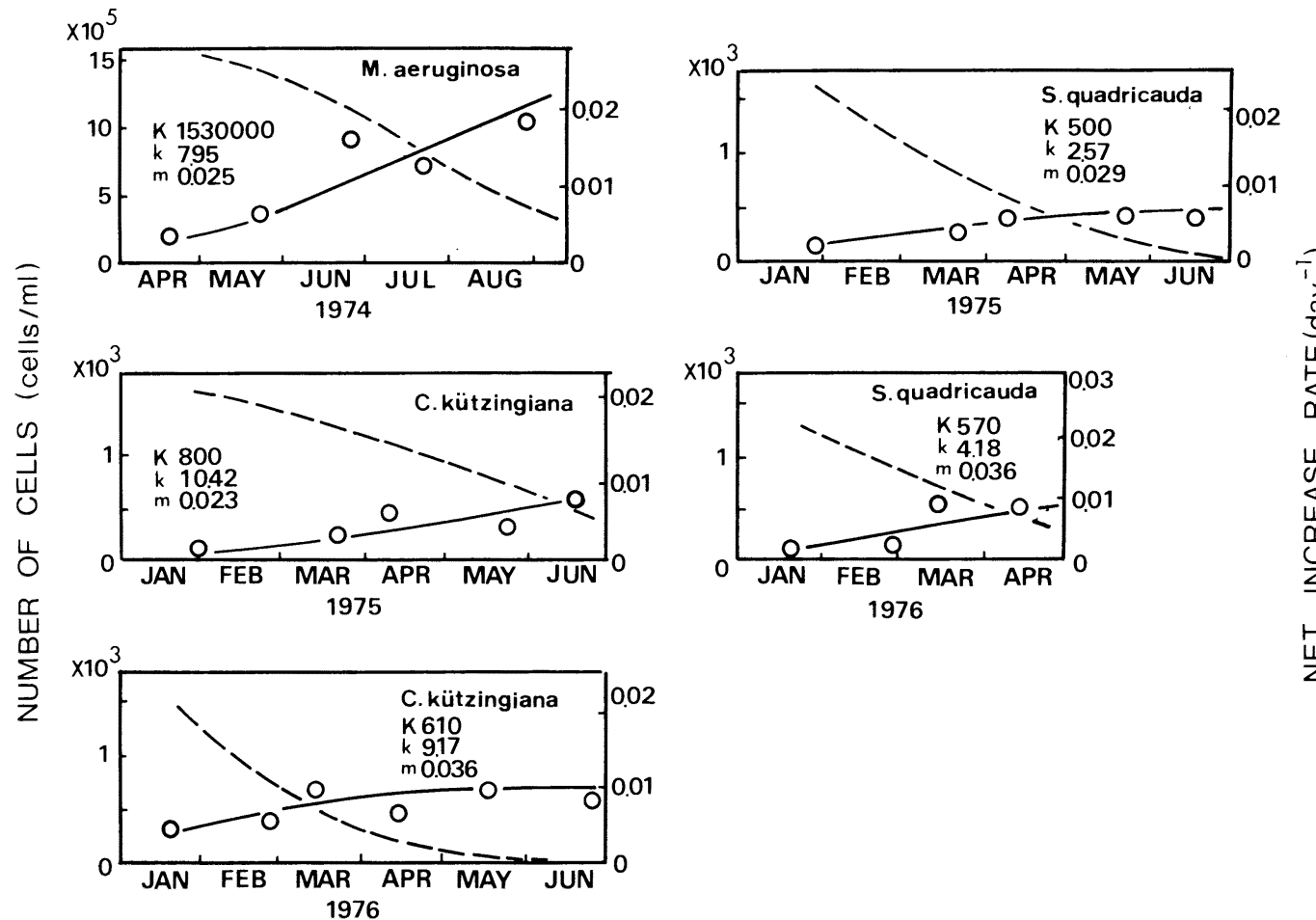

Fig. 1. Seasonal changes in number of cells $(O)$ and net increase rates (dashed line) of three phytoplankton populations in hypereutrophic Himonya Pond and eutrophic Lake Nakanuma. The increase curves (solid line) were calculated by use of the logistic equation, Eq. $1 . K, k$ and $m$ are the parameters of the logistic equation.

Table 1. Maximum number of cells $(K)$, integration constant $(k)$ and intrinsic growth rate $(m)$ for three phytoplankton populations.

\begin{tabular}{lccc}
\hline & $\begin{array}{c}K \\
\left(\text { cells } \cdot \mathrm{ml}^{-1}\right)\end{array}$ & $k$ & $\begin{array}{c}m \\
\left(\text { day }^{-1}\right)\end{array}$ \\
\hline M. aeruginosa & $1,530,000$ & 7.95 & 0.025 \\
C. kützingiana & $610-800$ & $9.17-10.42$ & $0.023-0.036$ \\
S. quadricauda & $500-570$ & $2.57-4.18$ & $0.029-0.036$ \\
\hline
\end{tabular}

when the $j$-th nutrient concentration was zero.

The values of the parameters in Eq. (3) are shown in Table 2. $\alpha_{i j}$ ranged from 0.031 in $S$. quadricauda to 0.021 in $M$.. aeruginosa. $\beta_{i j}$ for total inorganic nitrogen was low in $M$. aeruginosa, and high in $C$. kuitzingiana and S. quadricauda. Conversely, $\beta_{i j}$ for phosphate phosphorus was high in $M$. aeruginosa, and low in $C$. kützingiana and $S$. quadricauda. These parameter values imply that $M$. aeruginosa may increase even in low concentrations of total inorganic nitrogen, and $C$. kützingiana and $S$. quadricauda may increase in low concentrations of phosphate phosphorus.

3-3. Population dynamics in the model phytoplankton assemblage

On the basis of the relationship between the net increase rates of phytoplankton populations and the ambient concentrations of nutrients, the population dynamics in the model phytoplankton assemblage were analyzed under two nutrient conditions, hypereutrophic and slightly eutrophic. The model phytoplankton assemblage was assumed to be 

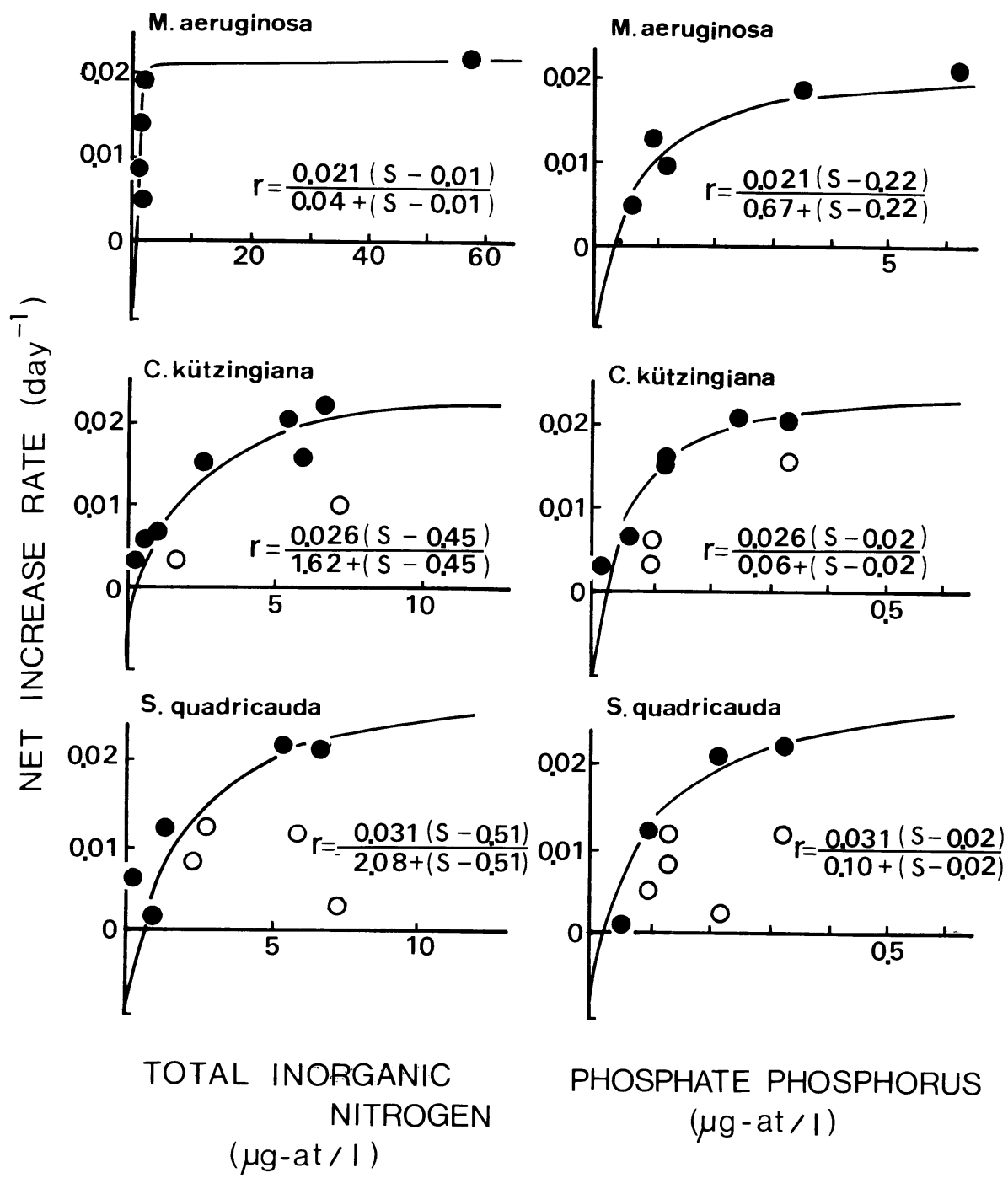

Fig. 2. Relationship between the net increase rate

and $\bigcirc$ ) and the concentrations of total inorganic nitrogen and phosphate phosphorus. The values represented by solid circles were used in calculating the parameters of the hyperbolic equation, Eq. 3 , in the figure.

composed of three species, $M$. aenuginosa, $C$. kützingiana and $S$. quadricauda, the net increase rates of which were controlled by two nutrients, total inorganic nitrogen and phosphate phosphorus. The net increase rate $\left(r_{i}\right)$ of each phytoplankton population was expressed by the following equation,

$$
r_{i}=\operatorname{MIN}\left[\frac{\alpha_{i j}\left(s_{j}-s_{i j}^{\prime}\right)}{\beta_{i j}+\left(s_{j}-s_{i j}^{\prime}\right)}\right]
$$

The parameters, $\alpha_{i j}, \beta_{i j}$ and $s_{i j}^{\prime}$ for three phytoplankton species in Table 2 were used. This equation states that the net increase rate of each phytoplankton population is determined by the lowest rate estimated from either total inorganic nitrogen or phosphate phosphorus.

Using $r_{i j}$ estimated from Eq. (4), the increase in each population is

$$
n_{i t}=n_{i o} e^{r} i^{t}
$$

where $n_{i o}$ and $n_{i t}$ are the number of cells of the $i$ th population at time zero and time $t$, respectively.

The decrease in ambient nutrients (nitrogen and phosphate) caused by the growth can then be expressed as follows, 
Table 2. Parameters for Eqs. 3 and 4. $\alpha_{\mathrm{ij}}$ and $\beta_{\mathrm{ij}}$ are constants of the $i$-th species for the $j$-th nutrient, $s_{i j}^{\prime}$ is the ambient concentration of the $j$-th nutrient at which no increase of the $i$-th species population occurs, and $c_{i j}$ is the content of $j$-th nutrient in cells of the $i$-th species.

\begin{tabular}{|c|c|c|c|c|c|}
\hline Species & Nutrient & $\begin{array}{c}\alpha_{\mathrm{ij}} \\
\left(\mathrm{day}^{-1}\right)\end{array}$ & $\begin{array}{c}\beta_{\mathrm{ij}} \\
\left(\mu \mathrm{g} \sim \mathrm{at} \cdot \mathrm{l}^{-1}\right)\end{array}$ & $\begin{array}{c}s_{i j}^{\prime} \\
\left(\mu \mathrm{g}-\mathrm{at} \cdot \mathrm{1}^{-1}\right)\end{array}$ & $\begin{array}{c}c_{i j} \\
\left(\mu \mathrm{g}-\mathrm{at} \cdot \mathrm{cell}^{-1}\right)\end{array}$ \\
\hline \multirow[t]{2}{*}{ M. aenuginosa } & $\mathrm{N}$ & 0.021 & 0.04 & 0.013 & $3.75 \times 10^{-7}$ \\
\hline & $\mathrm{P}$ & 0.021 & 0.67 & 0.216 & $1.43 \times 10^{-8}$ \\
\hline \multirow[t]{2}{*}{ C. kützingiana } & $\mathrm{N}$ & 0.026 & 1.62 & 0.452 & $1.10 \times 10^{-6}$ \\
\hline & $\mathrm{P}$ & 0.026 & 0.06 & 0.017 & $7.33 \times 10^{-7}$ \\
\hline \multirow[t]{2}{*}{ S. quadricauda } & $\mathrm{N}$ & 0.031 & 2.08 & 0.507 & $1.39 \times 10^{-6}$ \\
\hline & $\mathrm{P}$ & 0.031 & 0.10 & 0.024 & $9.26 \times 10^{-7}$ \\
\hline
\end{tabular}

$$
s_{j t}=s_{j o}-\Sigma c_{i j}\left(n_{i t}-n_{i o}\right)
$$

where $s_{j o}$ and $s_{j t}$ are the ambient concentrations of the $j$-th nutrient at time zero and time $t$, respectively, and $c_{\mathrm{ij}}$ is the content of the $j$-th nutrient in a cell of the $i$-th $\operatorname{species}\left(\mu \mathrm{g}\right.$-at $\cdot$ cell $\left.^{-1}\right)$.

As the first step in estimating parameter $c_{i j}$ (that is, nitrogen content and phosphorus content in each cell of $M$. aenginosa, $C$. kützingiana and $S$. quadricauda), the carbon content in a cell was calculated from the cell volume of each species by using the STrathmax equation (1967). Then, the nitrogen content was determined from the carbon content by use of a $\mathrm{C}: \mathrm{N}$ ratio of 3.5 (ANTia et al., 1963). The phosphate content per cell was estimated from the nitrogen content per cell by using an $\mathrm{N}$ : P ratio of 25 for $M$. aeruginosa and 15 for both $C$. kützingiana and S. quadricauda. The results are summarized in Table 2.

The initial concentrations of total inorganic nitrogen and phosphate in waters $\left(s_{j o}\right)$ were assumed to be $100 \mu \mathrm{g}$-at $\mathrm{N} \cdot \mathrm{l}^{-1}$ and $10 \mu \mathrm{g}$-at $\mathrm{P} \cdot \mathrm{l}^{-1}$ for hypereutrophic water, and $10 \mu \mathrm{g}-$ at $\mathrm{N} \cdot 1^{-1}$ and 1 $\mu \mathrm{g}-$ at $\mathrm{P} \cdot \mathrm{l}^{-1}$ for slightly eutrophic water. These nutrient concentrations frequently occur in surface waters of lakes in spring. The initial number of cells of each species was assumed to be 10,000 cells . $\mathrm{ml}^{-1}$ for hypereutrophic waters and $1,000 \mathrm{cells} \cdot \mathrm{ml}^{-1}$ for slightly eutrophic waters.

By the repetitive use of Eqs. (4), (5) and (6), successive changes in each population under given conditions were calculated. The results are illustrated in Figures 3 and 4 . Under the hypereutrophic conditions (Fig. 3), three species populations increased equally in the first 25 days because of abundant nutrients. During this period, total inorganic nitrogen decreased rapidly and reached a low level of $4.3 \mu \mathrm{g}$-at $\mathrm{N} \cdot \mathrm{l}^{-1}$. On the contrary, phosphate still remained at a high level of $7.9 \mu \mathrm{g}$ at $\mathrm{P} \cdot \mathrm{1}^{-1}$. After 25 days both $C$. kützingiana and $S$. quadricauda did not show any increase, because the population increases of these species cannot be maintained in nitrogen-depleted waters, as shown in Figure 2. On the other hand, $M$. aenuginosa increased exponentially and reached $2.2 \times 10^{5}$ cells. $\mathrm{ml}^{-1}$ after 180 days, and accounted for $89.3 \%$ of the total number of cells in the phytoplankton assemblage. This is because the population increase of $M$. aenuginosa is maintained in nitrogen-depleted waters, as shown in Figure 2. Diversity of this phytoplankton assemblage finally dropped to a low level of 0.57 .

In slightly eutrophic waters (Fig. 4), C. kützingiana and $S$. quadricauda increased faster than $M$. aenuginosa in the first 35 days. During this period, total inorganic nitrogen and phosphate phosphorus decreased to $1.2 \mu \mathrm{g}$-at $\mathrm{N} \cdot \mathrm{l}^{-1}$ and 0.87 $\mu \mathrm{g}$-at $\mathrm{P} \cdot \mathrm{l}^{-1}$, respectively. After 35 days, $C$. kützingiana and $S$. quadricauda no longer increased because of nitrogen depletion. $M$. aenginosa continued to increase, but did not develop into such a large population as in the hypereutrophic conditions, because of the low level of phosphate phosphorus in the slightly eutrophic waters. The population dynamics predicted by the present model were consistent with the results obtained from the field survey (O(iAWA and IcHInL RA 1984).

\section{Discussion}

\section{4-1. Relationship between population increase of phytoplankton and nutrient concen- tration}

The present study showed that $M$. aenginosa potentially increased with low ambient concentrations of inorganic nitrogen, while $C$. kützingiana and $S$. quadricauda potentially increased with low 


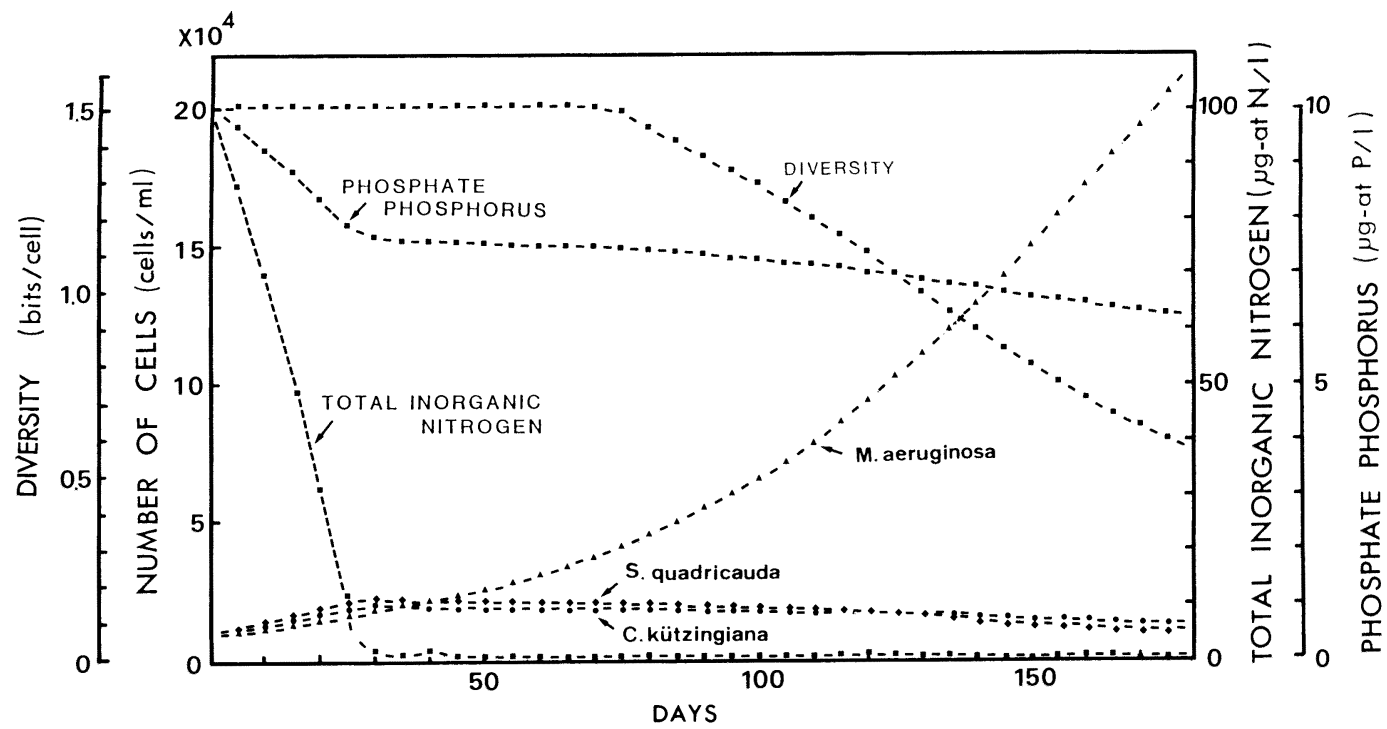

Fig. 3. Model estimations of population increase of $M$. aeruginosa, C. kützingiana and S. quadricauda under hypereutrophic conditions. Initial concentrations of total inorganic nitrogen and phosphate phosphorus were $100 \mu \mathrm{g}$-at $\mathrm{N} \cdot \mathrm{l}^{-1}$ and $10 \mu \mathrm{g}$-at $\mathrm{P} \cdot \mathrm{l}^{-1}$, respectively.

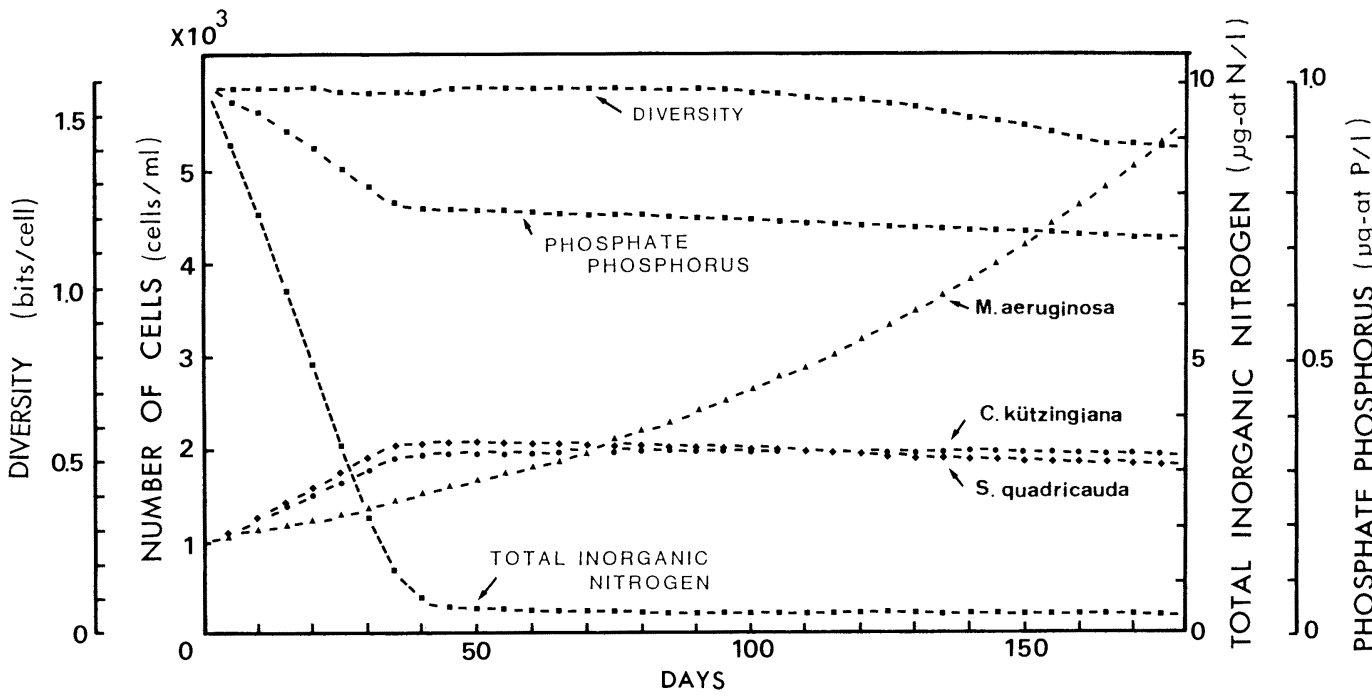

Fig. 4. Model estimations of population increase of $M$. aeruginosa, C. kützingiana and S. quadricauda under slightly eutrophic conditions. Initial concentrations of total inorganic nitrogen and phosphate phosphorus were $10 \mu \mathrm{g}$-at $\mathrm{N} \cdot 1^{-1}$ and $1 \mu \mathrm{g}$-at $\mathrm{P} \cdot 1^{-1}$, respectively.

ambient concentrations of phosphate. These results were supported by the studies based on the laboratory culture. RHEE and GoTHAM (1981) investigated the $\mathrm{N}$ : $\mathrm{P}$ ratio at which switching occurs from nitrogen-limited growth to phosphate-limited growth. They showed that Microcystis sp. moves from nitrogen-limited growth to phosphate-limited growth at a low N : P ratio, whereas Scenedesmus quadricauda transits at a high $\mathrm{N}: \mathrm{P}$ ratio. Furthermore, Holm and ARMSTRONG (1981) reported that $M$. aeruginosa has a high $K_{s}$ value for phosphatelimited growth. Their results suggest that $M$. aeruginosa is limited more by phosphorus than by nitrogen. 


\section{4-2. Model building}

For simplification of model building, several assumptions were made in the present study. The net increase rates of phytoplankton populations were estimated from Eq. (4), which was a function of the concentration of total inorganic nitrogen and phosphate phosphorus. If the net increase rate varied depending on the combination of temperature, light, sinking and grazing, it would be unreasonable to estimate the net increase rates only from Eq. (4). However, the net increase rates estimated from Eq. (4) reflect not only the influence of the in situ concentration of the nutrients but also the complex effects of other environmental factors, because the parameters in Eq. (4) were determined on the basis of net increase rates under complex conditions of ambient nutrient concentrations and other environmental factors. Theoretically, at a given nutrient concentration, infinite combinations of other environmental factors can be assumed. In temperate waters, however, these combinations are definite, because there are some correlations between environmental factors. For example, high nutrient concentrations are associated with low temperature and low light intensity in spring, whereas low nutrient concentrations are associated with high temperature and high light intensity in summer. Thus, since other environmental conditions can be roughly determined from nutrient concentrations, each net increase rate can be estimated from Eq. (4) under complex conditions correlated with each nutrient concentration.

Furthermore, in the present study, luxury consumption was ignored. Phytoplankton species were assumed to incorporate only the amount of nutrients necessary for growth. The nutrient contents of the cells were assumed to be constant. The effects of luxury consumption on population dynamics may be analyzed by a model in which nutrient uptake is regulated by ambient concentrations of nutrients, and growth is controlled by intracellular nutrient concentrations. However, because of lack of available data of parameters for this model, a model in which in situ nutrient concentrations control phytoplankton population growth was used. TILMAN (1977) showed that both models predicted similar results in phytoplankton dynamics. Therefore, the present model may be adequate for rough simulation of phytoplankton communities.

\section{4-3. Population dynamics of phytoplankton species}

TILMAN (1977) studied the competition between two phytoplankton species which were limited by two nutrients in the steady-state system, and explained the relative abundance of phytoplankton species in the river plume and the offshore region of Lake Michigan. He emphasized that the supply ratio of the two limiting nutrients determines the outcome of the competition. According to his theory, when the ratio of the two limiting nutrients is extremely high or extremely low, the nutrient in lower supply may decrease faster than the other nutrient, and may limit the growth of both phytoplankton species. Therefore, phytoplankton species that can use the limiting nutrient will replace the other species. When the ratio is intermediate, one nutrient limits one species and the other nutrient limits the other species. Therefore, in some cases, two phytoplankton species grow at the same rate and coexist.

The present study investigated the population dynamics of phytoplankton species in non-steady state systems, in which limiting nutrients were supplied only at the initial stage. The results imply that the amounts of nutrients, rather than the ratio of limiting nutrients, control the population dynamics in seasonal changes of phytoplankton species. In the present study, the ratios of the concentration of total inorganic nitrogen to that of phosphate phosphorus were 10 in both hypereutrophic and eutrophic conditions. Total inorganic nitrogen decreased to the limiting level faster than phosphate phosphorus in both conditions. Since $M$. aemginosa can use lower concentrations of nitrogen than $C$. kützingiana and $S$. quadricauda (Fig. 2), M. aeruginosa will replace the other two species. In hypereutrophic conditions, a large amount of phosphate phosphorus allowed $M$. aeruginosa to develop into a large population, and the diversity of the phytoplankton community decreased. In slightly eutrophic conditions, however, since the low concentration of phosphate phosphorus limited $M$. aeruginosa, it did not develop into a large population, and the diversity remained at a high level. These results imply that the amount of nutrients plays an important role in seasonal change of phytoplankton species.

\section{Acknowledgements}

I wish to thank Prof. Dr. S. Ichimura, Japanese 
Red Cross College of Nursery, for his critical reading of the manuscript.

\section{摘 要}

過栄養および富栄養条件における植物プ ランクトン個体群の純增加速度と動態

過栄養の碑文谷池挹よび富栄養の中沼に扔いて， Microcystis aenuginosa, Cyclotella kützingiana 拈よ び Scenedesmus quadricauda の各植物プランクトン 個体群の増加速度と水中の栄養塩濃度との関係を調 ベ，双曲線関数で近似した。 M. aeruginos $a$ は, 他の 2 種よりも，より低い濃度の無機窒素のもとで増加す ることが可能であり, 一方, C. kiutzingiana と $S$. quadricauda は, $M$. aeruginosaより, 上り低い濃度 のリン酸のもとで増加することが可能であった。

これらの関係をもとにした数学モデルにより，過栄 養条件とわずかに富栄養な条件に打けるこれら植物プ ランクトン個体群の動態を解析した。過栄養条件では, 多量に存在するリン酸態りンが， $M$. aeruginosa を大 個体群にまで発達させ，群集の多様度を低下させた。

一方，わずかに富栄養の条件では，リン酸態リンの量 が乏しいため，いずれの種も大個体群にまで発達する ことができず，多様度は高く維持された。モデルの予 測する結果は, 野外での観測結果と一致し,また，植 物プランクトンに利用可能な栄養塩の総量が, 植物プ ランクトン個体群の動態を支配する.上で重要な要因と なることが示唆された。

\section{References}

Antia, N. J., D. Macalister, T. R. Parsons, K. STEPHENS (1963): Further measurements of primary production using a large volume plastic sphere. Limnol. Oceanogr., 8 :166-183.

Carpenter, E. J. and R. R. L. Guillari) (1971) : Interspecific differences in nitrate half-saturation constants for three species of marine phytoplanton. Ecology, 52 :183-185.

CAPERON, J. (1967) : Population growth response in microorganisms limited by food supply. Ecology, $48: 715-722$.

Ducibal., R. C. (1967) : Nutrient limitation in the sea : dynamics, identification and significance.
Limnol. Oceanogr., $12: 196-206$.

Eppley, R. W. and W. H. Thomas (1969) :Com. parison of half-saturation constants for growth and nitrate uptake of marine phytoplankton. J. Phycol., 5 :375-379.

Hold, N. P. and D. E. Arustrong; (1981) : Role of nutrient limitation of Asterionella formosa and Microcystis aenginosa in semicontinuous cultrue. Limnol. Oceanogr., $26: 622-634$.

Lund, J. W. G. and J. F. TAlling (1957) : Botanical limnological methods with special reference to the algae. Bot. Rev., $23: 489-583$.

OGAWA, Y. and S. ICHIMURA (1984) : The relationship between phytoplankton diversity and trophic status of inland waters. Jap. J. Ecol., 34: 27-33.

Rhee, G-Y. and I. J. Gotham (1980) : Optimal N : $P$ ratios and the coexistence of planktonic algae. J. Phycol., $16: 486-489$.

Shanion, C. E. and W. Wealer (1963): The' mathematical Theory of Communication. 125pp. The university of Illinois Press.

Strathiax R. R. (1967) : Estimating the organic carbon content of phytoplankton from cell volume or plasma volume. Limnol. Oceanogr., 12: 411-418.

Strickland, J. D. H. and T. R. PArsons (1972) : A practical handbook of seawater analysis. Fish. Res. Bd. Canada, Bull., 167, 311pp.

TILMAN, D. (1977) : Resource competition between planktonic algae : an experimantal and theoreticl approach. Ecology 58 : 338-348.

(著者：小川吉夫 筑波大学生物科学系, $\overline{\mathbf{T}} 305$ 茨 城県つくば市天王台 1-1-1; 現住所, 日本大学薬学部 生物学研究室, 干 274 千葉県船橋市習志野台 7-7-1：

Yoshio OGAWA, Institute of Biological Sciences, University of Tsukuba,Tennoudai, Tsukuba 305 : present address, Laboratory of Biology, College of Pharmacy, Nihon University, Narashinodai, Funabashi 274)

Received : 17 February 1988

Accepted : 13 September 1988 